\title{
PERAN TEKNOLOGI INFORMASI DAN KOMUNIKASI DALAM PENDIDIKAN
}

\author{
Haris Budiman. \\ harisbudaiman@ radenintan.ac.id \\ Universitas Islam Negeri Raden Intan Lampung
}

\begin{abstract}
This study aims to determine the role of information and communication technology in education. The information and communication technology in general aims to make students understand information and communication technology devices in general, including computers (literacy) and information literacy, which means students recognize the terms used in information and communication technology. In the Qur'an there are so many commands, statements, suggestions, satires and so on that substantially link Islamic teachings to science and technology. The results of this study found that the role of information technology in education, in addition to helping students in learning also had a quite influential role for teachers, especially in the use of facilities to enrich teaching skills, and the Qur'an as a guide and guidance for the development of science and technology in order to strengthen faith and improve human well-being.
\end{abstract}

Keywords:Information Technology and Education.

\begin{abstract}
Abstrak
Penelitian ini bertujuan untuk mengetahui peran teknologi informasi dan komunikasi dalam pendidikan. Adapun teknologi informasi dan komunikasi secara umum bertujuan untuk membuat siswa memahami perangkat teknologi informasi dan komunikasi secara umum, termasuk komputer (literasi) dan literasi informasi, yang artinya siswa mengenali istilah yang digunakan dalam teknologi informasi dan komunikasi. Di dalam Al-Qur'an ada begitu banyak perintah, pernyataan, saran, satir dan sebagainya yang secara substansial menghubungkan ajaran Islam dengan sains dan teknologi. Hasil penelitian ini menemukan bahwa peran teknologi informasi dalam pendidikan, selain membantu siswa dalam belajar juga memiliki peran yang cukup berpengaruh bagi guru, terutama dalam penggunaan fasilitas demi memperkaya kemampuan mengajar, dan Al-Qur'an sebagai pedoman dan petunjuk bagi pengembangan sains dan teknologi dalam rangka mempertebal keimanan dan meningkatkan kesejahteraan manusia.
\end{abstract}

Kata Kunci: Teknologi Informasi dan Komunikasi. 


\section{PENDAHULUAN}

Hidup manusia sangat dipengaruhi oleh perkembangan ilmu pengetahuan dan teknologi.Teknologi misalnya banyak menghasilkan mesin dan alat-alat seperti jam, mesin jahit, mesin cetak, mobil, kapal terbang, dan lain sebagainya, agar manusia dapat hidup lebih mudah, aman, dan senang dalam lingkungannya.Alat-alat tersebut juga menimbulkan macam-macam bahaya yang dapat merusak dan membahayakan hidup manusia.

Hasil teknologi telah sejak lama dimanfaatkan dalam pendidikan. Penemuan kertas, mesin cetak, radio, film, TV, komputer dan lain-lain itu dimanfaatkan bagi pendidikan.Pada hakekatnya alat-alat tersebut tidak dibuat khusus untuk keperluan pendidikan, akan tetapi alat-alat tersbut ternyata dapat dimanfaatkan dalam dunia pendidikan.

Perkembangan teknologi informasi yang semakin pesat di era globalisasi saat ini tidak bisa dihindari lagi pengaruhnya terhadap dunia pendidikan. Tuntutan global menuntut dunia pendidikan untuk selalu dan senantiasa menyesuaikan perkembangan teknologi terhadap usaha dalam peningkatan mutu pendidikan, terutama penyesuaian penggunaannya bagi dunia pendidikan khususnya dalam proses pembelajaran. Teknologi informasi merupakan perkembangan sistem informasi dengan menggabungkan antara teknologi komputer dengan telekomunikasi (Baharudin, 2010).

Institusi pendidikan di Indonesia mulai berlomba-lomba mememanfaatkan Teknologi Informasi dan Komunikasi (TIK) untuk pendidikan dengan membangun infrastruktur hardware, jaringan internet, pengadaan sofware dan lain sebagainya, yang semua itu dilakukan dalam usaha memenuhi kebutuhan akan metode pembelajaran yang lebih efektif dan efisien. Pelatihan-pelatihan dengan pemanfaatan aplikasi komputer pun sering diselenggarakan seperti; Intelligent Tutoring System (ITS), Computer Basad Training (CBT), dan e-Learning System (Hariningsih, 2005).

Globalisasi telah memicu kecenderungan pergeseran dalam dunia pendidikan dari pertemuan tatap muka yang konvensional ke arah pendidikan yang lebih ke arah terbuka. Pendidikan masa mendatang akan bersifat luwes (fleksibel), terbuka dan dapat diakses oleh siapapun yang memerlukan tanpa pandang faktor jenis usia, maupun pengalaman pendidikan sebelumnya. Pendidikan masa mendatang akan lebih ditentukan 
oleh jaringan informasi yang memungkinkan berinteraksi dan kolaborasi, bukan berorientasi pada gedung sekolah.

Kecendrungan perubahan dan inovasi dalam dunia pendidikan akan terus terjadi dan berkembang dalam memasuki abad ke- 21 sekarang ini. Perubahan tersebut antara lain: lebih mudah dalam mencari sumber belajar, lebih banyak pilihan untuk menggunakan dan memanfaatkan ICT, makin meningkatnya peran media dan multi media dalam kegiatan pembelajaran.

Kecendrungan perubahan dan inovasi tersebut, memiliki implikasi yang sangat luas dalam dunia pendidikan, yaitu perubahan dalam program pembaruan dan teknologi pembelajaran, perubahan dalam program belajar dan pembelajaran dengan menggunaka metode ekspremental, pengendalian belajar lebih kepada peserta didik, peningkatan $\mathrm{IQ}$ (intlelligence quontient) yang diimbangi dengan pembinaan EQ (emotional qoutient), dan SQ (spritual qoutient), serta menuntut pengintegrasian TIK dalam kegiatan pembelajaran.

Teknologi dapat meningkatkan kualitas dan jangkauan apabila digunakan secara bijak untuk pendidikan dan latihan, dan mempunyai arti yang sangat penting bagi kesejahteraan.

Menurut (B. Uno, 2010) mengatakan bahwa kecendrungan pendidikan di Indonesia di masa mendatang adalah sebagai berikut :

1. Berkembangnya pendidikan terbuka dengan modus belajar jarak jauh (distance learing). Kemudianuntuk menyelenggarakan pendidikan terbuka dan jarak jauh perlu dimasukkan sebagai strategi utama;

2. Shareng resource bersama antar lembaga pendidikan/latihan dalam sebuah jaringan perpustakaan dan istrumen pendidikan lainnya (guru, laboratorium) berubah fungsi menjadi sumber informasi daripada sekedar rak buku;

3. Penggunaan perangkat teknologi informasi interaktif, seperti CD-ROM multi media dalam pendidikan secara bertahap menggantikan televisi dan video.

Adanya perkembangan teknologi dan informasi dalam dunia pendidikan, maka pada saat itu sudah dimungkinkan untuk diadakan belajar jarak jauh dengan menggunakan media internet untuk menghubungkan antara mahasiswa dengan dosennya, melihat nilai mahasiswa secara online, mengecek keuangan, melihat jadwal kuliah, mengirimkan berkas tugas yang diberikan dosen dan sebagainya. 
Pemanfaatan TIK yang telah merambah dalam bidang pendidikan, sejak dimasukan dalam kurikulum 2004. Tujuannya supaya mahasiswa dapatmengoptimalkan keterampilannya, sehingga dapat diaplikasikan pada mata pelajaran lain sebagai lintas kurikulum(Budiman, 2012).

Penggunaan TIK dalam pendidikan sangat bermanfaat, hal ini dibuktikan oleh penelitian terdahulu yaitu oleh (Abrianto \& Sitompul, 2014; Gunawan, 2016; Idris, 2015; Khairunnisa, 2017; Riasnelly, 2013; Roza, 2010; Sunarwan, 2013). Penggunaan TIK juga tidak hanya bermanfaat dalam proses pembelajaran saja melainkan TIK dapat digunakan dalam beberapa penelitian umum, seperti yang dilakukan oleh (Andriyani, Cangara, \& Sadjad, 2014; Budiman, Yusrizal, \& Damanik, 2014; Febriani, 2012; Kristiyono, 2015; Santoso, 2014).

Perubahan akan tuntutan itulah yang menjadikan dunia pendidikan memerlukan inovasi dan kreativitas dalam proses pembelajarannya karena banyak orang mengusulkan dalam pendidikan khususnya pembelajaran, akan tetapi sedikit sekali orang berbicaratentang solusi pemecahan masalah tentang proses belajar dan mengajar yang sesuai dengan tuntutan global abad ke 21 saat ini.

Berdasarkan masalah di atas maka tujuan penelitian ini yaitu untuk mengetahui peran teknologi informasi dan komunikasi. Adapun keterbaruan dalam penelitian ini yaitu penelitian ini akan mengkaji pandangan Islam terhadap teknologi dan pentingnya agama dalam perkembangan teknologi.

\section{HASIL KAJIAN DAN PEMBAHASAN}

A. Pengertian Teknologi Informasi Pendidikan

Kemajuan ilmu dan teknologi informasi telah banyak mengubah cara pandang dan gaya hidup masyarakat Indonesia dalam menjalankan aktivitas dan kegiatannya. Keberadaan dan peranan teknologi informasi dalam sistem pendidikan telah membawa era baru perkembangan dunia pendidikan, tetapi perkembangan tersebut belum diimbangi dengan peningkatan sumber daya manusia yang menentukan keberhasilan dunia pendidikan di Indonesia pada umumnya. Hal ini lebih desebabkan masih tertinggalnya sumber daya manusia kita untuk memanfaatkan teknologi informasi dalam proses pendidikan tersebut. 
Peningkatan kinerja pendidikan di masa mendatang diperlukan sistem informasi dan teknologi informasi yang tidak hanya berfungsi sebagai sarana pendukung, tetapi lebih sebagai senjata utama untuk mendukung keberhasilan dunia pendidikan sehingga mampu bersaing di pasar global.

Pola pikir perlu dibangun agar dapat mengikuti perkembangan TI yang sangat cepat. Pola pikir yang dimaksud adalah berpikir diluar kotak(think out of the box).Pada pola pikir ini dapat digambaarkan bahwa dalam penyelesaian masalah menggunakan cara-cara yang mungkin belum dipikirkan oleh kebanyakan orang.Pada saat pesawat terbang belum ditemukan banyak orang berpikir bahwa mustahil menerbangkan sesuatu yang lebih berat daripada udara, sehingga mustahil benda sebesar pesawat terbang sekarang ini dapat terbang.Hal tersebut merupakan pemikiran orang zaman dahulu sebelum pesawat terbang ditemukan, tetapi sekarang pemikiran tersebut dipatahkan dengan ditemukannya jet yang menjadi tenaga pendorong pesawat terbang saat ini.Oleh karena itulah bagaimana kita mampu membentuk peserta didik yang kreatif, inovatif,berpikir kritis, problem solver, dan kewirausahaan, hal ini dimungkinkan tentu tidak terlepas dari ikut andilnya TIK dalam kehidupan dunia pendidikan saat ini.

Pengertian informasi sering disamakan dengan pengertian data.Data adalah sesuatu yang belum diolah dan belum dapat digunakan sebagai dasar yang kuat dalam pengambilan keputusan.Beberapa contoh data adalah data nama mahasiswa, jumlah kursi, jumlah peserta didik dan lain-lain. Data nama mahasiswa relatif belum berarti jika digunakan untuk mengambil keputusan tertentu. Data nama mahasiswa ditambah data IPK mahasiswa dan presentase nilai "D" dapat digunakan untuk menentukan bahwa mahasiswa tersebut dapat mengambil bebas teori atau tidak. Data bebas teori dan nilai skripsi dapat digunakan untuk mengambil keputusan bahwa mahasiswa tersebut berhak lulus atau tidak. Hasil gabungan dari data nama mahasiswa, IPK, presentase nilai "D", dan nilai skripsi barulah dapat dikatakan sebagai sebuah informasi.

Posisi TIK perlu digambarkan, sehingga keberadaanya menjadi jelas.Posisi TI sering disamakan dengan TIK ataubahkan dianggap lebih luas dibandingkan dengan TIK, sehingga sering salah dalam menentukan posisinya. TIK memiliki bidang kajian yang bermacam-macam, karena dalam TIK tidak hanya membahas masalah teknologi informasi dan komputer, tetapi juga membahas teknologi komunikasi/telekomunikasi. Adapun kajian TIK menurut (Diat, Prasojo, 2011)adalah sebagai berikut : 1) $e$ - 
Learning; 2) manajemen informasi; 3) teknologi informasi; 4) teknologi komputer; 5) sistem informasi mamajemen; 6) internet; 7) teknologi telekomunikasi(handpone, telepon, teknologi kabel dan nirkabel); 8) teknologi jaringan komputer; 9) Sitem keamanan jaringan komputer; 10) sistem basis data. Dengan demikian dapatlah dikatakan bahwa TI merupakan bagian dari bidang ilmu TIK yang pada implementasinya saling terkait satu sama lainnya.

Perubahan di dalam semua segi kehidupan manusia dewasa ini terutama disebabkan karena kemajuan ilmu dan teknologi .Terjadinya perubahan besar tersebut oleh karena sumber kekuatan dan kemakmuran suatu masyarakat atau negara bukan lagi ditentukan oleh luas wilayahnya atau kekayaan sumber daya alamnya yang melimpah, tetapi telah berpindah kepada penguasaan dan pemanfatan ilmu pengetahauan dan teknologi.

Menurut Christine E. Sleeter \& Peter L dalam (Tilaar, AR, 2012),mengatakan bahwa terdapat tiga kekuatan yang dominan yaitu :1). Ilmu pengetahuan, 2) Teknologi sebagai penerapan pengetahuan, 3) Informasi.

Ketiga kekuatan ini tidak berhubungan lagi secara langsung dengan nasionalitas.Ilmu dan pengetahuan tidak perlu menyeberangi tapal batas suatu negara dan oleh sebab itu tidak lagi memerlukan paspor dan visa.Demikian pula dengan informasi berhembus kemana-mana tanpa batas dan tidak ada yang dapat menghentikan atau menghambat.Inilah era informasi yang memberikan skenario baru yang penuh dengan kemungkinan-kemungkinan.Kemungkinan-kemungkinan tersebut terus dieksplorasi sesuai dengan kemajuannya. Teknologi informasi telah mengubah kebudayaan negara menuju kebudayaan global karena sekat-sekat yang mengesolasikan kehidupan berbagai masyarakat dan negara telah dihapuskan. Kemajuan teknologi telah mempercepat proses globalisasi dan menuntut penataan kembali kehidupan umat manusia dalam berbagai segi baik itu ekonomi, perdagangan, aliran modal maupun lembaga-lembaga kerjasama internasional lainnya.

Teknologi Informasi dan Komunikasi adalah payung besar terminologi yang mencakup seluruh peralatan teknis untuk memproses dan menyampaikan informasi. TIK mencakup dua aspek yaitu teknologi informasi dan teknologi komunikasi. Teknologi informasi meliputi segala hal yang berkaitandengan proses, penggunaan sebagai alat bantu, manipulasi, dan pengelolaan informasi. Sedangkan teknologi komunikasi adalah segala sesuatu yang berkaitan dengan penggunaan alat bantu untuk 
memproses dan mentransfer data dari perangkat yang satu ke lainnya. Oleh karena itu, teknologi informasi dan teknologi komunikasi adalah dua buah konsep yang tidak terpisahkan. Jadi Teknologi Informasi dan Komunikasi mengandung pengertian luas yaitu segala kegiatan yang terkait dengan pemrosesan, manipulasi, pengelolaan, pemindahan informasi .

B. Pandangan Islam Terhadap Teknologi

Agama merupakan salah satu struktur institusional penting yang melengkapi keseluruhan sistem sosial.Akan tetapi masalah agama berbeda dengan masalah pemerintahan, hukum yang lazim menyangkut alokasi serta pengendalian kekuasaan.Berbeda pula dengan lembaga ekonomi yang berkaitan dengan kerja, produksi dan pertukaran/perdagangan.

Sebenarnya lembaga keagamaan adalah menyangkut hal yang mengandung arti penting tertentu menyangkut masalah aspek kehidupan manusia, yang dalam tendensinya menyangkut sesuatu yang mempunyai arti sangat penting bagi manusia, bahkan sejarah menunjukkanbahwa lembaga-lembaga keagamaan merupakan bentuk asosiasi manusia yang paling mungkin untuk terus tetap bertahan.

Kecendrungan kehidupan dunia saat ini memang sangat dipengaruhi oleh pesatnya teknologi informasi dan komunikasi dan kemajuan pengetahuan dengan segala dampaknya, baik yang bersifat positif maupun yang bersifat negatif.Hal ini pulalah yang mendorong terjadinya arus globaliosasi yang mengalir derasnya serta membuahkan berbagai implikasi yang demikian luas dalam segala aspek kehidupan manusia serta bangsa-bangsa di dunia.

Ketika manusia berhadapan dengan kemajuan teknologi yang berkembang dengan pesat serta berada dalam era percaturan mondial yang ditandai dengan berkembangnhya sikap dan gaya hidup global, disini peranan agama sebagai pengendali sikap dan prilaku dalam kehidupan manusia maupun sebagai landasan, etika, moral dan spritual masyarakat suatu bangsa dalam melaksanakan pembangunan nasionalnya menjadi semakin penting dan menentukan.

Pandangan Islam tentang teknologi dapat diketahui prinsip-prinsipnya seperti yang dikemukakan oleh(Rais, 1998), yang tertuang dalam surat Al-Mujadalah ayat 11, yang artinya “...Allah akan mengangkat orang-orang yang beriman diantara kamu sekalian dan yang berilmu pengetahan beberapa derajat”. 
Agama Islam banyak memberikan penegasan mengenai ilmu dan pengetahuan baik secara nyata maupun secara tersamar seperti yang tersebut juga dalam surat Al-Alaq, ayat 1-5 yang artinya :Bacalah dengan (menyebut) nama Tuhanmu yang menciptakan. Dia telah menciptakan manusia dari segumpal darah.Bacalah dan Tuhanmulah yang maha pemurah.Yang mengajar (manusia) dengan perantara kalam.Dia mengajarkan kepadaти apa-apa yang tidak diketahui.

Berdasarkan wahyu pertama tersebut tidak menjelaskan apa yang dimaksud dengan iqra (apa yang harus dibaca), karena Al-Qur'an menghendaki umatnya membaca apa saja selama bacaan tersebut bermanfaat bagi umat manusia. Iqra berarti bacalah, telitilah, dalamilah, ketahuilah ciri-ciri sesuatu baik yang tertulis maupun yang tidak tertulis. Islam adalah agama Allahyang disyariatkannya sejak Nabi adam sa, hingga Nabi Muhammad SAW kepada umat manusia. Islam mewajibkan kepada umatnya untuk mengamini kebenaran tersebut.Akar masalah dari agama adalah kepercayaan terhadap kebenaran mutlak yang pasti membawanya kearah kebaikan dan kemanfaatan, bukan kepada kemudaratan.

Manusia banyak mendapatkan pengalaman dalam kehidupannya.Pengalaman itu didapatkan sejumlah pengetahuan yang memiliki sifat tertentu tanpa kemampuan untuk menjelaskan sebab-sebabnya secara terinci dan rasional.Setiap manusia berbeda jumlah dan macamnya, pengalaman yang dimiliki tanpa adanya kemampuan untuk menjelaskannya, dengan demikian perlu didukung oleh sejumlah kegiatan berikutnya yang lebih serius guna mendapatkan inti sari pengetahuan tersebut hingga dapat dipedomani untuk perencanaan, prediksi-prediksimaupun kontrol atas kebenarannya.Kombinasi usaha mencari pendekatan rasional dan pengumpulan faktafakta empiris inilah yang bisa disebut dengan pendekatan mendapatkan pengetahuan dengan metode keilmuan.

Orang yang berilmu berarti menguasai ilmu dan menjelaskannya. Untuk mendapatkannya diperlukan antara lain adanya sarana tertentu yakni yang disebut berpikir, yaitu suatu proses untuk mendapatkan pengetahuan. Oleh karena itu apabila didalam Al-qur'an sering disebut dengan kata-kata berpikir atau berpikirlah dan sebagainya dalam arti langsung maupun dalam arti sindiran dapat kita artikan juga sebagai perintah mencari ilmu dan mencari pengetahuan. 
Al-Qur'an dan al-Hadits sangat banyak yang menerangkan ayat-ayat tentang hubungan antara ajaran Islam dan pengetahuan serta pemanfaaatannya yang kita sebut iptek.Hubungan tersebut dapat berbentuk semacam perintah yang mewajibkan, menyuruh mempelajari pernyataan-pernyataan, bahkan ada yang berbentuk sindiransindiraan dan sebagainya. Kesemuanya itu tidak lain menggambarkan betapa eratnya hubungan antara Islam dan Iptek sebagai hal yang tidak dapat dipisahkan satu dengan lainnya sebagaimana yang tersebut juga dalam surat Yunus, ayat 101, yang artinya:Lakukanlah penelitian secara intensif mengenai apa-apa yang ada dilangit dan apa-apa yang ada dibumi.

C. Pentingnya Agama Dalam Perkembangan Teknologi

IPTEK mempunyai peran yang semakin penting dalam kehidupan umat manusia, malahan ada yang berpendapat bahwa Iptek merupakan unsur yang terpenting untuk memperoleh kesejahteraan umat manusia.Hakekat nilai sesungguhnya melekat pada diri pendidik sebagai pelaksanadari pendidikan, sedangkan pendidikan merupakan proses transformasi dan internalisasi ilmu pengetahuan dan nilai-nilai Islam pada peserta didik melalui penumbuhan dan pengembangan potensi fitrahnya untuk mencapai keseimbangan dan kesempurnaan hidup dalam segala aspeknya(Sada, 2015).

Perkembangan Iptek yang sangat cepat dan berlangsung terus menerus membawa perubahan dalam pola kehidupan umat manusia dipenghujung akhir abad ke- 20, untuk itu umat manusia harus mampu menyusun skenario masa depannya secara konfrehensif sehingga kembali memimpin, sebagai penggerak dan pelopor dalam Ilmu dan teknologidi abad ke- 21, abad atau era globalisasi yang penuh dengan persaingan.

Kalau kita perhatikan sebagai indikasi bahwa belum banyak kemajuan dalam bidang Iptek yang dapat dibanggakan oleh umat Islam. Hal tersebut dikarenakan oleh beberapa faktor, antara lain : masih melekatnya pandangan yang sempit sebagian besar umat Islam dalam memahami dan menerjemahkan ajaran agama Islam dalam kehidupannya, seperti pengertian "Ulama" hanya orang-orangyang menguasi bidang agama saja. Orientasi ajaran agama hanya tertuju pada fikih semata .Seharusnya pola pikir umat Islam perlu disempurnakan dan berorientasi fikih iptek sebagai landasan berpikir dan bertindak disamping Al-Qur'an dan As-sunnah, juga ayat-ayat kauniah (ayat-ayat yang digelar Allah di alam semesta). 
Suatu hal yang sangat menarik adalah bahwa Al-Qur'an sangat menganjurkan manusia untuk memperhatikan bahwa meneliti alam dan menemukan ayat-ayat Allah yang mengatur fenomena alam itu. Ibnu Rosydi dalam (Faisal. A. Yusuf, 1997), seorang sarjana muslim yang sangat terkenal itu pernah mengatakan bahwa alam raya ini adalah kitab Allah yang pertama sebelum kitab Allah lain yang berbentuk kumpulan wahyunya.

Praktek sunatullah yang dikemukakan oleh para ilmuan menemukan sesuatu fenomena yang tanpa disangka-sangka dalam hal ini dapat dikatakan bahwa tidak semua pengertian dapat dilaksanakan hasil sebagaimana yang diinginkan, bahkan tidak jarang pula suatu kegagalan sekaligus meminta korban berupa kerugian baik materi bahkan jiwa. Ayat Al-Qur'an banyak sekali menganjurkan pada manusia untuk meneliti alam semesta ini demi menjayakan mereka dalam beramal soleh, maka mudahlah bagi kita untuk memahami mengapa Allah menjanjikan kepada setiap umat Nabi Muhammad yang beriman dan beramal soleh mendapatkan mafirah/ampunan dan ganjaran yang besar dari Allah SWT.

QS. 48:29, mengatakan “.....Allah menjanjikan kepada orang-orang beriman dan mengerjakan amal yang soleh diantara mereka ampunan dan pahala yang besar"

Allah mengakui betapa sulitnya usaha umatnya untuk memahami sunnah-Nya yang diwahyukan itu, sehingga diperlukan penelitian-penelitian yang selalu dihadang oleh kegagalaan dan kehilapan manusia. Demi menjauhkan rasa takut dan bimbang manusia akan melakukan kesalahan dan Allah telah menjanjikan ampunan terlebih dahulu. Dengan demikian manusia mu'minyang dikenal para saintis dan para teknolog tidak perlu bimbang dalam melaksanakan segala aktivitas penelitian dan percobaanpercobaan, karena Allah memberikan ampunan bagi mereka.

Hal inilah yang memberikan dorongan bagi para ulama kita dari beberapa generasi sesudah Rasul Allah, yang terkenal dengan para tabi'inuntuk belajar dengan mengadakan penelitian-penelitian dan percobaan-percobaan dengan penuh gairah, hal tersebut di dorong oleh pemahaman mereka tentang ayat-ayat dan pesan Rasulallah SAW. Ciri khas nyata dari science yang tidak dapat diingkari meskipun oleh para ilmuan adalah bahwa ia tidak mengenal kata akekal. Apa yang dianggap salah di masa silam misalnya boleh jadi dapat dianggap dan diakui kebenarannya diabad modern. 
Pandangan terhadap persoalan ilmiah silih berganti bukan saja dalam lapangan pembahasan satu ilmu saja tetapi juga dalam teori-teori setiap cabang ilmu maupun pengetahuan. Dahulu, misalnya segala sesuatu diterangkan dalam konsep material(kebendaan) sampai-sampai manusiapun hendak dikategorikan dalam konsep tersebut. Sekarang ini kita dapati ilmu psikologi yang membahas mengenai jiwa, budi dan semangat, telah mengambil tempat tersendiri dan mempunyai peranan yang sangat penting dalam kehidupan manusia.Dahulu persoalan-persoalan moral kurang mendapatkan perhatian para ilmuan, tetapi kini dalam penggunaan senjata-senjata bertenaga nuklirpun tidak dapat dilepaskan dari persoalan tersebut, mereka tidak dapat mengabaikan persoalan moral dalam penggunaan senajata nuklir yang merupakan hasil dari kemajuan Teknologi.

Dengan demikian jelaslah bahwa ilmu dan pengetahuan hanya melihat dan menilik bukan menetapkan.Ia melukiskan fakta-fakta, objek-objek dan fenomena-fenomena yang dilihat mata seorang ilmuan ia mempunyai sifat pelupa, keliru ataupun tidak mengetahui. Karenanya jelas pulalah bahwa apa yag dikatakan orang sebagai ssuatu yang benar (kebenaran ilmiah) sebenarnya hanya merupakan suatu hal yang sangat relatif dan terbatas.

\section{SIMPULAN DAN SARAN}

Perkembangan teknologi informasi yang semakin pesat di era globalisasi saat ini tidak bisa dihindari lagi pengaruhnya terhadap dunia pendidikan.Tuntutan global menuntut dunia pendidikan untuk selalu dan senantiasa menyesuaikan perkembangan teknologi terhadap usaha dalam peningkatan mutu pendidikan, terutama penyesuaian penggunaan nya bagi dunia pendidikan khususnya dalam proses pembelajaran.Dalam dunia pendidikan, bertujuan agar siswa memahami secara umum, termasuk komputer( computer literate) dan memahami informasi (information literate), artinya siswa mengenal istilah-istilah yang digunakan pada teknologi informasi dan komunikasi.Peran teknologi informasi dalam pembelajaran, selain membantu siswa dalam belajar juga memiliki peran yang cukup berpengaruh bagi guru terutama dalam pemanfaatan fasilitas untuk kepentingan memperkaya kemampuan mengajarnya.

Dalam Al-Qur'an banyak sekali kita jumpaiperintah-perintah, keterangan, anjuran, sindiran dan sebagainya yang pada hakekatnya sangat konsen atau kental sekali yang 
mengaitkan antara ajaran Islam dengan ilmu pengetahuan dan teknologi.Umat Islam meyakini bahwa agama Islam adalah agama Allah yang sempurna.Al-Qur'an adalah kitabullah yang berisi petunjuk dan pedoman yang lengkapuntuk mengkaji seluruh kehidupan manusiakearah kebahagiaan yang hakiki dan yang abadi.Al-Qur'an juga mengandung ayat-ayat yang dapat di jadikan pedoman meskipun hanya secara garis besar bagi pengembangan sains dan teknologi dalam rangka mempertebal keimanan dan meningkatkan kesejahteraan manusia.

\section{DAFTAR PUSTAKA}

Abrianto, D., \& Sitompul, H. (2014). Penggunaan Media Pembelajaran Berbasis Komputer Dan Sikap Inovatif Terhadap Hasil Belajar Teknologi Informasi Dan Komunikasi. Jurnal Teknologi Informasi \& Komunikasi Dalam Pendidikan, 1(1), $50-62$.

Andriyani, O., Cangara, H., \& Sadjad, R. S. (2014). Penggunaan Teknologi Informasi Online Dalam Kecepatan Pelayanan Dan Pengamanan Pada Bank BCA Makassar (Sebuah Studi Komunikasi Organisasi). Jurnal Komunikasi KAREBA, 3(1), 58-67.

B. Uno, H. . (2010). Teknologi Komunikasi dan Informasi Pembelajaran. Jakarta: Bumi Aksara.

Baharudin, R. (2010). Keefektifan Media Belajar Berbasis Teknologi Informasi Dan Komunikasi. Tadrîs, 5(1), 112-127.

Budiman, M. A. (2012). Pemanfaatan Teknologi Informasi dan Komunikasi dalam Kelas Bahasa Inggris. Semantik, 2(1), 9-14.

Budiman, Yusrizal, \& Damanik, J. (2014). Akses Dan Penggunaan Teknologi Informasi Dan Komunikasi Pada Rumah Tangga Dan Individu. Jurnal Penelitian Komunikasi Dan Pembangunan, 15(1), 1-16.

Diat, Prasojo, L. (2011). Teknologi Informasi Pendidikan. Yogyakarta: Gaya Media.

Faisal. A. Yusuf. (1997). Mu'jizat Al-Qur'an dan As-Sunnah Tentang IPTEK. Jakarta: Andalan.

Febriani, Y. (2012). Peran dan Masalah Teknologi Informasi dan Komunikasi dalam Hubungan Percintaan Tokoh Utama dalam Roman " Megaherz " Karya Bas Böttcher. Students E-Journal, 1(1).

Gunawan, A. (2016). Pemanfaatan Teknologi Informasi Dan Komunikasimelalui Penggunaan Media Pendidikan Dalam Pembelajaran IPS SD. Pedagogi Jurnal Penelitian Pendidikan Volume, 3(2), 16-24. 
Hariningsih, S. (2005). Teknologi Informasi. Yogyakarta: Graha Ilmu.

Idris. (2015). Efektifitas Penggunaan Teknologi Informasi Dan Komunikasi Dalam Pembelajaran Pendidikan Agama Islam. Jurnal Potensia vol.14, 14(2), 175-190.

Khairunnisa, R. (2017). Penggunaan Media Berbasis Teknologi Informasi dan Komunikasi (TIK) dalam Peningkatan Kemampuan Menulis Puisi Siswa Kelas III B SDN 005 Awang Long Samarinda. Jurnal Pendas Mahakam, 2(1), 100-107.

Kristiyono, J. (2015). Budaya Internet: Perkembangan Teknologi Informasi Dan Komunikasi Dalam Mendukung Penggunaan Media Di Masyarakat. Jurnal SCRIPTURA, 5(1), 23-30. https://doi.org/10.9744/scriptura.5.1.23-30

Rais, M. A. (1998). Al-Islam dan Iptek. Jakarta: Perumus Fakultas Tehnik UMJ.

Riasnelly. (2013). Efektifitas Penggunaan Media Teknologi Informasi Dan Komunikasi (TIK) Dalam Kemampuan Menyusun Kalimat Pada Anak Tunarungu Di SLB Tanjung Pinang. E-JUPEKhu, 1(2), 122-133.

Roza, Y. (2010). Analisis Penggunaan Teknologi Komunikasi Dan Informasi Pada Sekolah Di Kota Pekanbaru Propinsi Riau. Jurnal Pendidikan, 1(1), 1-7.

Sada, H. J. (2015). Pendidik Dalam Perspektif Al-Qur'an. Al-Tadzkiyyah: Jurnal Pendidikan Islam, 6(1), 93-105.

Santoso, D. H. (2014). Pemanfaatan Teknologi Komunikasi dan Informasi pada Erupsi Merapi 2010 di Sleman Yogyakarta. Jurnal Pekommas, 17(3), 181-188.

Sunarwan, B. (2013). Pola Penggunaan Teknologi Informasi Dan Komunikasi (TIK)Di Lingkungan Masyarakat Pedesaan (Survei pada Komunitas Anggota Penerima PNPM Provinsi Jambi). Jurnal Studi Komunikasi Dan Media, 17(2), 149-162.

Tilaar, AR, H. (2012). Perubahan Sosial dan Pendidikan. Jakarta: Rineka Cipta. 